\title{
High Prevalence of Multiple Human Papillomavirus Infection in Japanese Patients with Invasive Uterine Cervical Cancer
}

\author{
Hidemichi Watari $^{a}$ Rie Michimata ${ }^{b, c}$ Motoaki Yasuda ${ }^{d}$ Akihiro Ishizu $^{e}$ \\ Utano Tomaru $^{\mathrm{b}}$ Ying Xiong $^{\mathrm{a}}$ Mohamed K. Hassan $^{\mathrm{a}}$ Noriaki Sakuragi $^{\mathrm{a}}$ \\ Departments of a Obstetrics and Gynecology, and b Pathology, Hokkaido University Graduate School of

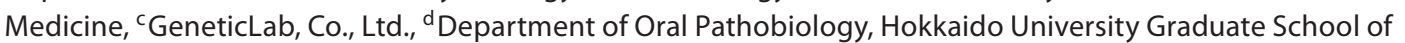 \\ Dental Medicine, ${ }^{e}$ Faculty of Health Sciences, Hokkaido University, Sapporo, Japan
}

\section{Key Words}

Human papillomavirus, multiple infection · Cervix uteri · Array technology

\begin{abstract}
Objective: Multiple human papillomavirus (HPV) infection of the uterine cervix has been suggested as a risk factor for persistent HPV infection, resulting in the development of invasive cervical cancer. The aim of this study was to reveal the actual state of multiple HPV infection in Japanese patients with invasive cervical cancer. Methods: Sixty fresh-frozen invasive cervical cancer tissues were examined for genotyping of HPV. The presence of HPV genotypes was determined with an HPV-DNA array, which can discriminate 25 different HPV genotypes with high sensitivity and specificity. Results: Among 60 samples, 59 (96.7\%) were positive for HPV. The three common genotypes were HPV-16 (83.3\%), HPV-18 (45.0\%) and HPV-52 (28.3\%). Multiple HPV infection was observed in 47 of 60 samples (78.3\%), among which 42 were infected with more than one high-risk genotype (70.0\%). Multiple high-risk HPV infection was significantly more prevalent in patients below 40 years old $(14 / 15,93.3 \%)$ than in patients 40 years of age and over (28/45, 62.2\%). Conclusion: The HPV-DNA array is the preferred method to detect HPV genotypes. Multiple HPV infection in Japanese patients with invasive cervical cancer seemed to be more frequent than reported in the literature.

Copyright $\odot 2011$ S. Karger AG, Basel
\end{abstract}

\section{KARGER}

Fax +4161306 1234

E-Mail karger@karger.ch

www.karger.com (c) 2011 S. Karger AG, Basel

1015-2008/11/0784-0220\$38.00/0

Accessible online at:

www.karger.com/pat

\section{Introduction}

Uterine cervical cancer is the second most common cancer in women worldwide. Certain genotypes of human papillomavirus (HPV) have been shown to be closely associated with the development of cervical cancer. Currently, more than 90 different HPV genotypes have been identified. Genotypes HPV-16, -18, -31, -33, -35, -39, $-45,-51,-52,-56,-58,-59$ and -66 are regarded as highrisk types because they are identified in high-grade squamous intraepithelial lesions (HSILs) and invasive cervical cancer tissues $[1,2]$. On the other hand, the genotypes HPV-6 and HPV-11 are considered as low-risk types [2]. Today, HPV genotyping information is clinically useful for the prognosis and therapy based on the risk [3].

The frequency of HPV genotypes detected in cervical cancer tissues varies according to several factors, including the method of HPV detection and the ethnicity. More sensitive and reliable methods rather than individual testing, such as polymerase chain reaction (PCR), restriction fragment length polymorphism and Southern blot, should be developed as screening tools for HPV detection. Conventional methods of individual detection of each genotype have been replaced by a high-throughput technology which can identify many HPV genotypes at once. In the

H.W., R.M. and M.Y. contributed equally to this work.
Akihiro Ishizu, $\mathrm{MD}, \mathrm{PhD}$

Faculty of Health Sciences

Hokkaido University

Kita-12, Nishi-5, Kita-ku, Sapporo (Japan)

Tel. +81 11706 3385, E-Mail aishizu@ med.hokudai.ac.jp 
Table 1. Clinicopathological characteristics of patients enrolled in this study

\begin{tabular}{lc}
\hline Factors & $\mathrm{n}$ \\
\hline Age & $60(100 \%)$ \\
-29 years & $3(5.0 \%)$ \\
$30-39$ years & $12(20.0 \%)$ \\
$40-49$ years & $15(25.0 \%)$ \\
$50-59$ years & $20(33.3 \%)$ \\
$\geq 60$ years & $10(16.7 \%)$ \\
Clinical stage & $60(100 \%)$ \\
Ib & $28(46.6 \%)$ \\
IIa & $2(3.4 \%)$ \\
IIb & $15(25.0 \%)$ \\
IIIa & $1(1.7 \%)$ \\
IIIb & $10(16.7 \%)$ \\
IVa & $3(5.0 \%)$ \\
IVb & $1(1.7 \%)$ \\
Histology & $60(100 \%)$ \\
Sq & $42(70.0 \%)$ \\
Non-Sq & $18(30.0 \%)$ \\
Lymph node metastasis & $49(100 \%)$ \\
Negative & $34(63.4 \%)$ \\
Positive & $15(36.6 \%)$ \\
\hline
\end{tabular}

present study, a DNA array-based method to detect 25 different HPV genotypes, containing the 12 high-risk types, was applied in order to detect multiple HPV infection. A recent study revealed that multiple HPV infection is a factor implicated in persistent HPV infection [4]. Some studies also indicated that persistent HPV infection is critically implicated in the development of cervical dysplasia $[4,5]$. Collectively, multiple HPV infection is likely to be associated with the development of cervical neoplasm. However, the prevalence of multiple HPV infection in invasive cervical cancer in Japan has not been elucidated. The quality of the template DNA is an important factor that can affect HPV genotyping results. Fresh specimens can yield DNA of better quality than formalin-fixed and paraffin-embedded tissues for amplification. Therefore, this study used fresh-frozen tissue specimens from consecutive patients newly diagnosed as having invasive cervical cancer and applied an HPV-DNA array to clarify the multiple HPV infection status.

\section{Materials and Methods}

\section{Patients}

A total of 60 invasive cervical cancers were obtained from archives of fresh-frozen tissues between the years of 1999 and 2004 at the Department of Gynecology of Hokkaido University, Sap- poro, Japan. Forty-nine surgical specimens were obtained by radical hysterectomy. Eleven biopsy specimens were taken from patients who received radiotherapy and/or platinum-based chemotherapy as the initial treatment. In both cases, $5-\mathrm{mm}^{3}$ cubic tissues were obtained from the inside of the tumors to avoid contamination of the extrinsic HPV. Patients' age ranged from 20 to 72 years with an average of 48.5 years (table 1). An oncologic gynecologist performed pelvic examination and staging of the women according to the International Federation of Gynecology and Obstetrics (FIGO) classification. Based on histological examinations, the tumors were divided into squamous cell carcinoma (Sq; 42 cases, $70.0 \%$ ) and non-squamous cell cacrinoma (non-Sq; 18 cases, $30.0 \%$ ). Non-Sq consisted of 13 endocervical adenocarcinomas, 3 adenosquamous carcinomas and 2 small-cell carcinomas. The status of lymph node metastasis of 49 patients who underwent radical hysterectomy was recorded.

\section{HPV-DNA Array}

The HPV-DNA array used in this study was designed to detect 12 high-risk HPVs (HPV-16/18/31/33/35/39/45/51/52/56/58/59), 2 intermediate-risk HPVs (HPV-30/53), 7 low-risk HPVs (HPV$6 / 11 / 34 / 40 / 42 / 54 / 61$ ), as well as 4 skin-type HPVs (HPV-17/ 20/21/47). The target sequences of these 25 genotypes and the G3PDH gene were amplified by PCR from the plasmids containing the genes using the primer sets listed in online supplementary table 1 (www.karger.com/doi/10.1159/000326770). Each $4 \mathrm{ng}$ of the amplified HPV-DNA and G3PDH sequence was purified using a spin column, and then blotted onto Hybond-N+ membrane (Amersham Biosciences, Tokyo, Japan). The schema of the HPVDNA array is shown as online supplementary figure 1 .

Genomic DNA was extracted from fresh-frozen tissues of 60 invasive cervical cancers using PureGene DNA isolation kit (Qiagen, Tokyo, Japan) and stored at $-2^{\circ} \mathrm{C}$ until use. For probe labeling, genomic DNA templates (100 ng) were amplified, using 26 sets of primers (including the primer sets for $25 \mathrm{HPV}$ genotypes and G3PDH, final $0.1 \mathrm{~mm}$ each, online suppl. table 1) and biotinylated dUTP (Roche Diagnostics, Tokyo, Japan). The cycle sequence was as follows: denaturation at $95^{\circ} \mathrm{C}$ for $20 \mathrm{~s}$, annealing at $52^{\circ} \mathrm{C}$ for $30 \mathrm{~s}$, and extension at $72^{\circ} \mathrm{C}$ for $30 \mathrm{~s}$ ( $\left.25 \mathrm{cycles}\right)$ followed by incubation at $72^{\circ} \mathrm{C}$ for $5 \mathrm{~min}$. The labeled probes were purified using a spin column and stored at $-20^{\circ} \mathrm{C}$ until use. The array membrane was prehybridized with PerfectHyb solution (Toyobo, Osaka, Japan) for $1 \mathrm{~h}$ at $72^{\circ} \mathrm{C}$. Then, the labeled probes (biotin-incorporated PCR products) were denatured, and then hybridized with the membrane. Hybridization was done at $72^{\circ} \mathrm{C}$ for more than $12 \mathrm{~h}$ followed by highly stringent washes at $72^{\circ} \mathrm{C}$. Signal detection was performed using the Phototope-Star Detection kit for nucleic acids (New England Biolabs, Ipswich, Mass., USA) and CDP-star (Roche Diagnostics) according to the manufacturers' protocols. Finally, chemiluminescent signals were measured using VersaDoc3000 system (BioRad Laboratories, Tokyo, Japan).

\section{Statistical Analysis}

The correlation between the status of HPV infection and the clinicopathological factors, including age, clinical stage, histology and lymph node metastasis, was examined. For statistical analysis, the $\chi^{2}$ test or Fisher's exact test was used. $p$ values $<0.05$ were considered to be significant. Statistical analyses were performed with Statview software (SAS Institute, Cary, N.C., USA). 


\section{Results}

\section{Specificity of the HPV-DNA Array}

To evaluate the specificity of the HPV-DNA array, the plasmid containing each sequence of HPV genotype (HPV-6/11/16/17/18/20/21/30/31/33/34/35/39/40/42/45/ $47 / 51 / 52 / 53 / 54 / 56 / 58 / 59 / 61$ ) or G3PDH was amplified by multiplex PCR, using the 26 sets of primers listed in online supplementary table 1 . When the labeled probes were hybridized with the array membranes, most primer sets were specific for the corresponding template DNA, though some cross-hybridization was seen between HPV20 and HPV-21 (fig. 1). Although further improvement is needed to prevent the cross-hybridization, we applied the HPV-DNA array for this study because HPV-20 and HPV-21 are skin-type HPVs.

\section{Genotypes Detected in Invasive Cervical Cancer}

Tissues by the HPV-DNA Array

Representative results of HPV detection in cervical cancer tissues by the HPV-DNA array are shown in figure 2. Data were considered to be valid only when the positive control signals of G3PDH were seen. All positive signals were validated by direct sequencing (data not shown). Table 2 summarizes the distribution of HPV genotypes according to histology. HPV was positive in 59 of 60 cases (98.3\%). Among high-risk types, HPV-16, -18, -31, -33, $-35,-52$, and -58 were detected. The most prevalent genotype was HPV-16 (50/60, 83.3\%), followed by HPV-18 (27/60, 45.0\%) and HPV-52 (17/60, 28.3\%). The prevalence of HPV-18 was significantly greater in Non-Sq $(14 / 18$, $77.8 \%)$ than in Sq $(13 / 42,31.0 \%)(\mathrm{p}=0.0008)$. HPV-52 and HPV-58 were observed exclusively in Sq. Among the lowrisk types, HPV-11 (17/60, 28.3\%) and HPV-34 (8/60, 13.3\%) were detected.

\section{Correlation between Multiple High-Risk HPV}

Infection and Clinicopathological Factors

In the present study, 47 of 60 patients (78.3\%) showed multiple HPV infection, in which the rate was much higher than the rates described previously [6-23] (table 3). Among the 47 patients, multiple high-risk HPV infection was observed in 42 patients $(42 / 60,70.0 \%$, table 4). To improve our understanding of the clinical significance of multiple high-risk HPV infection in invasive cervical cancer, the correlation between the status of multiple high-risk HPV infection and various clinicopathological factors was examined. Multiple high-risk HPV infection was observed in 14 of 15 (93.3\%) patients below 40 years old, and in 28 of 45 (62.2\%) patients 40 years of age and over. The difference in the positivity rate was statistically significant $(\mathrm{p}=0.03)$. Multiple high-risk HPV infection was not associated with clinical stage (Ib/II versus III/IV, $\mathrm{p}=0.95)$, histology (Sq versus Non-Sq, p = 0.71), and status of lymph node metastasis (negative versus positive, $\mathrm{p}=0.73$ ).

\section{Discussion}

HPV infection is considered a major causal factor of anogenital malignant lesions. Currently, more than 90 different HPV genotypes have been identified. The difficulty in HPV genotyping is due to the sequence homology of the viral genome, which will cause cross-hybridization with the Southern blot technique or unspecific amplification with the PCR method. Although DNA sequencing technology is able to distinguish each HPV genome sequence, it will require a lot of time and laboratory effort. Comprehensive HPV detection systems, including DNA array-based detection technology, may solve these problems. The HPV-DNA array system used in this study is a specific method to detect 25 different HPV genotypes without any significant cross-hybridization (fig. 1).

The International Agency for Research on Cancer reported that the top 5 prevalent HPV genotypes in invasive cervical cancer were HPV-16 (53\%), HPV-18 (15\%), HPV-45 (9\%), HPV-31 (6\%), and HPV-33 (3\%) [24]. In this study, the top 5 prevalent HPV genotypes were HPV-16 (83.3\%), HPV-18 (45.0\%), HPV-52 (28.3\%), HPV-31 (15.0\%), and HPV-58 (13.3\%). The high prevalence of HPV-16 and HPV-18 in Japanese patients with invasive cervical cancer is similar to the worldwide prevalence. The prevalence of HPV-18 was in this study was high as well. This may be attributed to the high proportion of adenocarcinoma in our patients because HPV-18 is closely associated with cervical adenocarcinoma rather than Sq [24]. Correspondingly, the prevalence of HPV-18 was significantly higher in Non-Sq $(14 / 18,77.8 \%)$ than in Sq $(13 / 42,31.0 \%)$ in the present study. On the other hand, the high prevalence of HPV-52 and HPV-58 in invasive Sq is a common finding in East Asia, including China, Hong Kong, Korea and Japan, compared to Western countries [24].

The most important issue in this study is that the prevalence of multiple HPV infection in Japanese patients with invasive cervical cancer is extremely high (47/60, 78.3\%). The reported incidence of multiple HPV infection in invasive cervical cancer varies greatly and ranges 

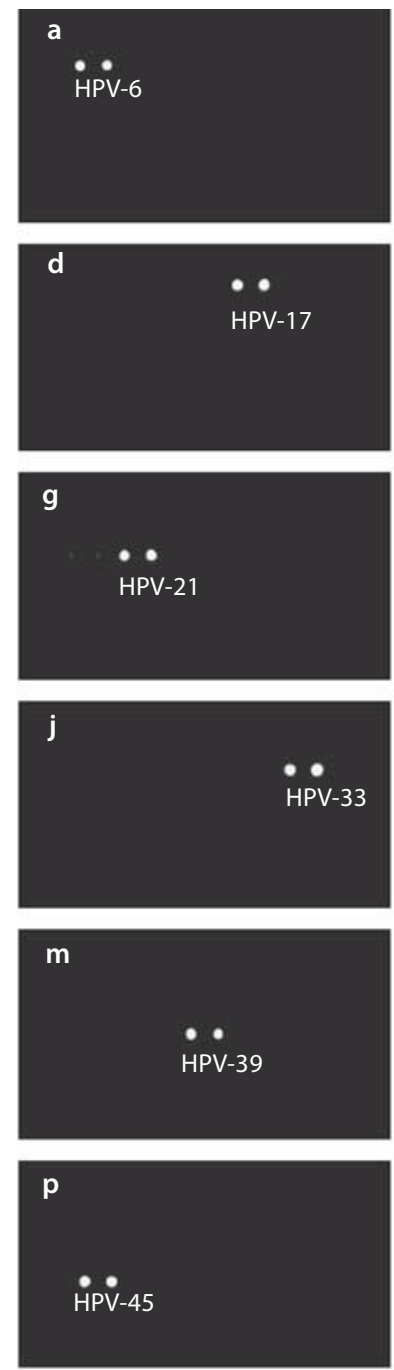

quence were used as templates: HPV-6 (a) HPV-11 (b), HPV-16 (c), HPV-17 (d), HPV18 (e), HPV-20 (f), HPV-21 (g), HPV-30 (h), HPV-31 (i), HPV-33 (j), HPV-34 (k), HPV-35 (I), HPV-39 (m), HPV-40 (n), HPV-42 (o), HPV-45 (p), HPV-47 (q), HPV-51 (r), HPV-52 (s), HPV-53 (t), HPV54 (u), HPV-56 (v), HPV-58 (w), HPV-59 (x), HPV-61 (y) and G3PDH (z). The templates were amplified using the 26 sets of primers (including the primer sets for the $25 \mathrm{HPV}$ genotypes and G3PDH) and biotinylated dUTP. The labeled probes were hybridized with the array membranes, and then signals were detected as described in the Materials and Methods section. Most primer sets were specific for the corresponding template DNA though some cross-hybridization was seen between HPV-20 and HPV-21.
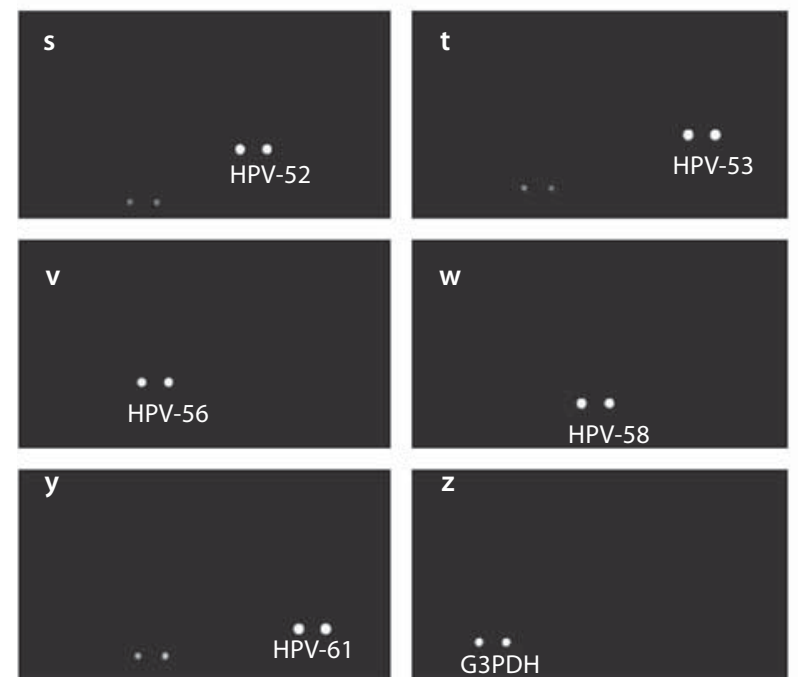
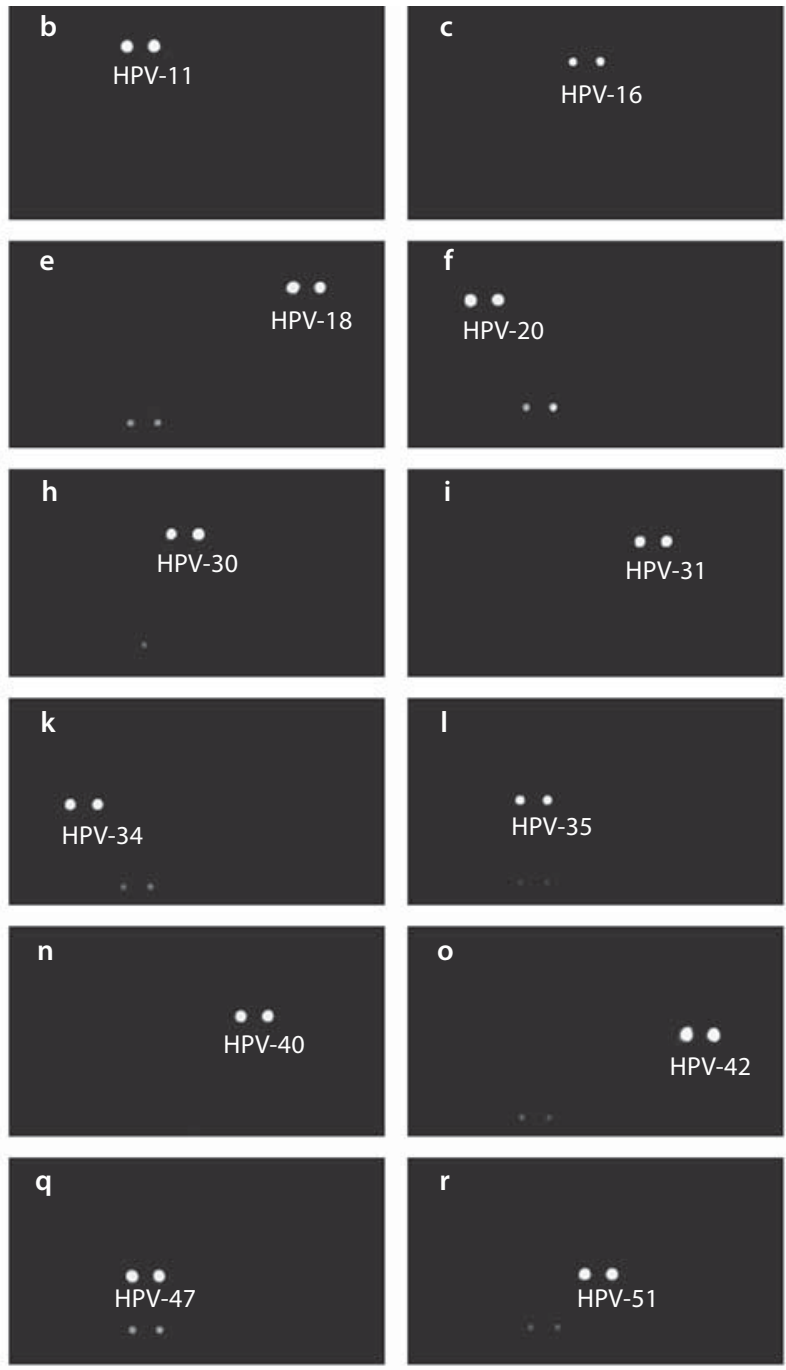

$\mathbf{u}$

HPV-54

$\mathbf{x}$ 

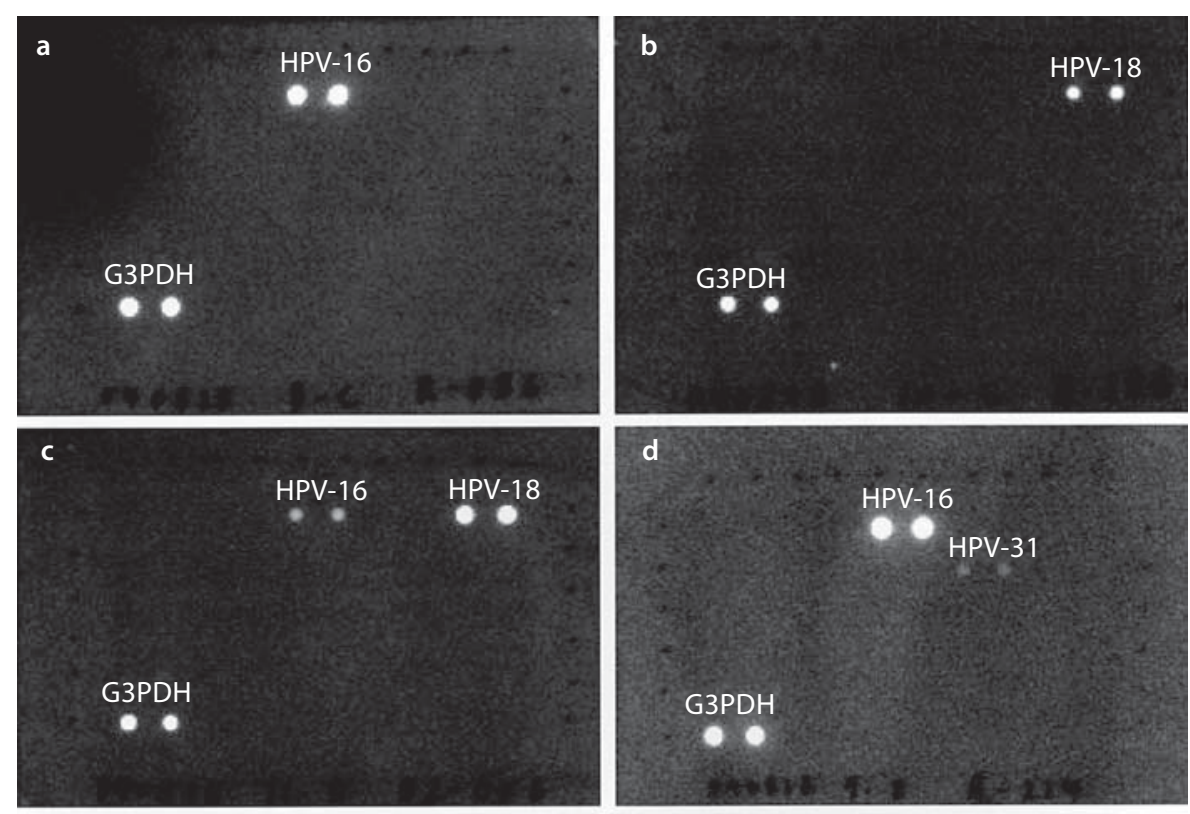

Fig. 2. Representative results of HPV detection by the HPV-DNA array. a, b Examples of single infection (a: HPV-16, b: HPV-18). c, d Examples of double infection (c: HPV-16/18, d: HPV-16/31). e Example of triple infection (HPV-16/18/52). f Example of quintuple infection (HPV-11/16/18/ 31/34).
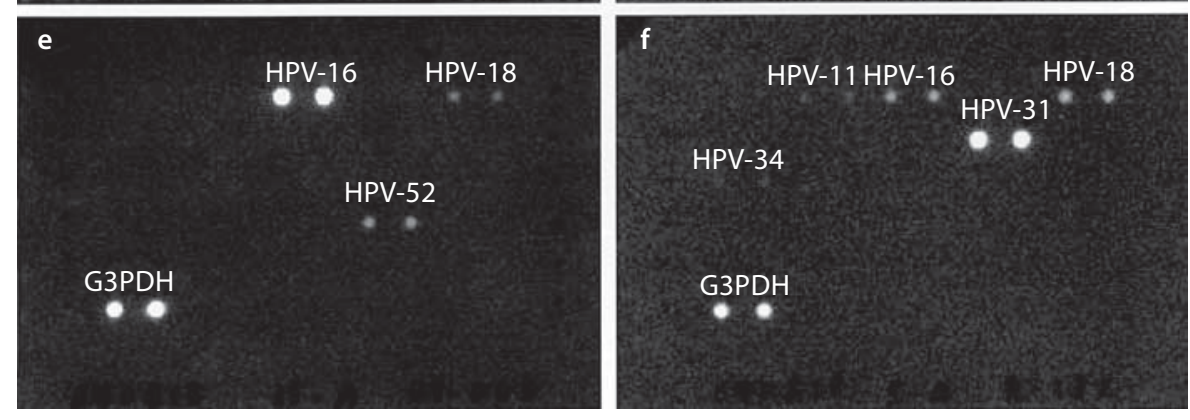

between 1.5 and $39.6 \%$ [6-23]. This result is, at least in part, due to the high sensitivity of the HPV-DNA array system and probably to the good quality of the template DNA used in this study. The DNA array system used in this study can detect $50 \mathrm{fg}$ of the HPV genomic DNA; therefore, it can detect the signal if more than 5 copies of the genotype virus are present (online suppl. fig. 2). In addition, fresh-frozen samples were employed in this study, though other researchers mostly used formalinfixed and paraffin-embedded tissues. It is well known that the duration of fixation and the type of fixative used affect the quality of the extracted nucleic acids. Degradation of DNA is the most common type of damage. Although a comparative study is needed to determine whether the frequency of multiple HPV infection in invasive cervical cancer in Japan is higher than that in other countries, our data suggest that the 'true' positivity rate of multiple HPV infection in invasive cervical cancer might be higher than that expected from previous reports.
The clinical significance of multiple HPV infection remains to be elucidated. Ho et al. [4] investigated the natural history of cervicovaginal HPVs and found an association between the presence of multiple HPV genotypes and the persistence (over 6 months) of infection. On the contrary, other studies showed that persistent HPV infection was independent of coinfection with other HPV genotypes $[25,26]$. The carcinogenic risk of multiple HPV infection is also controversial among reports. Lee et al. [27] reported that patients infected with multiple HPV genotypes had a 31.8-fold higher risk of cervical cancer while those infected with a single HPV genotype had a 19.9-fold increased risk. On the other hand, Sasagawa et al. [8] reported that the odds ratio of multiple HPV infection was 24 for low-grade squamous intraepithelial lesions, 16 for HSILs, and 8.3 for Sq of the cervix. The correct answer to the question about the association between multiple HPV infection and the pathogenesis of the disease may have to await further large-scale studies. 
Table 2. Distribution of HPV genotypes detected in 60 invasive cervical cancers

\begin{tabular}{|c|c|c|c|}
\hline \multirow{2}{*}{$\begin{array}{l}\text { HPV } \\
\text { genotype }\end{array}$} & \multicolumn{2}{|l|}{ Histology } & \multirow[t]{2}{*}{$\mathrm{n}$} \\
\hline & $\mathrm{Sq}(\mathrm{n}=42)$ & non-Sq $(\mathrm{n}=18)$ & \\
\hline \multicolumn{4}{|c|}{ High-risk type } \\
\hline 16 & 37 & 13 & $50(83.3 \%)$ \\
\hline 18 & 13 & 14 & $27(45.0 \%)$ \\
\hline 31 & 7 & 2 & $9(15.0 \%)$ \\
\hline 33 & 1 & 1 & $2(3.3 \%)$ \\
\hline 35 & 1 & 0 & $1(1.7 \%)$ \\
\hline 52 & 17 & 0 & $17(28.3 \%)$ \\
\hline 58 & 8 & 0 & $8(13.3 \%)$ \\
\hline \multicolumn{4}{|c|}{ Low-risk type } \\
\hline 11 & 13 & 4 & $17(28.3 \%)$ \\
\hline 34 & 7 & 1 & $8(13.3 \%)$ \\
\hline
\end{tabular}

Table 3. Frequency of multiple HPV infection in invasive cervical cancer

\begin{tabular}{lc}
\hline Authors & Multiple infection, n \\
\hline Kleter et al. [6] & $8 / 180(4.4 \%)$ \\
Rolon et al. [7] & $21 / 113(18.6 \%)$ \\
Sasagawa et al. [8] & $10 / 84(11.9 \%)$ \\
Schwarz et al. [9] & $36 / 362(9.9 \%)$ \\
Bachtiary et al. [10] & $42 / 106(39.6 \%)$ \\
Schellekens et al. [11] & $10 / 74(13.5 \%)$ \\
Matsukura et al. [12] & $29 / 250(11.6 \%)$ \\
Huang et al. [13] & $44 / 152(28.9 \%)$ \\
Huang et al. [14] & $48 / 149(32.2 \%)$ \\
Kim et al. [15] & $7 / 98(7.1 \%)$ \\
Stevens et al. [16] & $10 / 116(5.2 \%)$ \\
Lai et al. [17] & $370 / 2,046(18.0 \%)$ \\
Vermeulen et al. [18] & $28 / 157(17.8 \%)$ \\
Pretet et al. [19] & $115 / 516(22.0 \%)$ \\
Siriaunkgul et al. [20] & $21 / 96(21.9 \%)$ \\
Munagala et al. [21] & $7 / 40(17.5 \%)$ \\
Oh et al. [22] & $34 / 742(4.6 \%)$ \\
Mariani et al. [23] & $2 / 134(1.5 \%)$ \\
Present study & $47 / 60(78.3 \%)$ \\
\hline
\end{tabular}

In conclusion, our study demonstrated the high frequency of multiple HPV infection in Japanese patients with invasive cervical cancer, especially women below 40 years old. It would be worth establishing whether the presence of multiple HPV infection in the uterine cervix would be a marker for persistent HPV infection and progression of HPV-related diseases in the future.
Table 4. Prevalence of multiple high-risk HPV infection in invasive cervical cancers

\begin{tabular}{lccc}
\hline \multirow{2}{*}{ Factors } & \multicolumn{2}{c}{ Infection status } & \multirow{2}{*}{ p value } \\
\cline { 2 - 3 } & negative/single & multiple & \\
\hline Age & & & 0.03 \\
$\quad \leq 39$ years & 1 & 14 & \\
$\quad \geq 40$ years & 17 & 28 & \\
Clinical stage & & & 0.95 \\
$\quad$ Ib/II & 12 & 33 & \\
$\quad$ III/IV & 6 & 9 & 0.71 \\
Histology & & & \\
$\quad$ Sq & 12 & 30 & 0.73 \\
$\quad$ Non-Sq & 6 & 12 & \\
Lymph node metastasis & & & \\
$\quad$ Negative & 9 & 25 & \\
$\quad$ Positive & 3 & 12 & \\
\hline
\end{tabular}

\section{Acknowledgements}

We thank Prof. E.-M. de Villiers, Prof. M. Favre, Prof. A. Lorincz, Dr. T. Matsukura and Prof. T. Kiyono for providing fulllength HPV plasmids. This work was supported by a Grant-in-Aid for Scientific Research (B) (13576026) provided by the Ministry of Education, Science and Culture, Japan.

References Jayaprakash PG, Rajalakshmi TN, Devi CG, Nair MK, Nair MB: High-risk human papillomavirus infection and E6 protein expression in lesions of the uterine cervix. Pathobiology 1998;66:240-246.

- 2 Tornesello ML, Duraturo ML, Botti G, Greggi S, Piccoli R, De Palo G, Montella M, Buonaguro L, Buonaguro FM; Italian HPV Working Group: Prevalence of $\alpha$-papillomavirus genotypes in cervical squamous intraepithelial lesions and invasive cervical carcinoma in the Italian population. J Med Virol 2006;78:1663-1672.

-3 Meijer CJ, Snijders PJ, Castle PE: Clinical utility of HPV genotyping. Gynecol Oncol 2006;103:12-17.

- 4 Ho GY, Bierman R, Beardsley L, Chang CJ, Burk RD: Natural history of cervicovaginal papillomavirus infection in young women. N Engl J Med 1998;338:423-428.

5 Ho GY, Burk RD, Klein S, Kadish AS, Chang CJ, Palan P, Basu J, Tachezy R, Lewis R, Romney S: Persistent genital human papillomavirus infection as a risk factor for persistent cervical dysplasia. J Natl Cancer Inst 1995; 87:1365-1371. 
6 Kleter B, van Doorn LJ, Schrauwen L, Molijn A, Sastrowijoto S, ter Schegget J, Lindeman J, ter Harmsel B, Burger M, Quint W: Development and clinical evaluation of a highly sensitive PCR-reverse hybridization line probe assay for detection and identification of anogenital human papillomavirus. J Clin Microbiol 1999;37:2508-2517.

7 Rolon PA, Smith JS, Munoz N, Klug SJ, Herrero R, Bosch X, Llamosas F, Meijer CJ, Walboomers JM: Human papillomavirus infection and invasive cervical cancer in Paraguay. Int J Cancer 2000;85:486-491.

-8 Sasagawa T, Basha W, Yamazaki H, Inoue M: High-risk and multiple human papillomavirus infections associated with cervical abnormalities in Japanese women. Cancer Epidemiol Biomarkers Prev 2001;10:45-52.

-9 Schwartz SM, Daling JR, Shera KA, Madeleine MM, Mcknight B, Galloway DA, Porter PL, McDougall JK: Human papillomavirus and prognosis of invasive cervical cancer: a population-based study. J Clin Oncol 2001; 19:1906-1915.

10 Bachtiary B, Obermair A, Dreier B, Birner P, Breitenecker G, Knocke TH, Selzer E, Pötter R: Impact of multiple HPV infection on response to treatment and survival in patients receiving radical radiotherapy for cervical cancer. Int J Cancer 2002;102:237-243.

- 11 Schellekens MC, Dijkman A, Aziz MF, Siregar B, Cornain S, Kolkman-Uljee S, Peters LA, Fleuren GJ: Prevalence of single and multiple HPV types in cervical carcinomas in Jakarta, Indonesia. Gynecol Oncol 2004; 93:49-53.

12 Matsukura T, Sugase M: Human papillomavirus genomes in squamous cell carcinoma of the uterine cervix. Virology 2004;324: 430-439.

$\checkmark 13$ Huang LW, Chao SL, Chen PH, Chou HP: Multiple HPV genotypes in cervical carcinomas: improved DNA detection and typing in archival tissues. J Clin Viol 2004;29:271-276.
14 Huang HJ, Huang SL, Lin CY, Lin RW, Chao FY, Chen MY, Chang TC, Hsueh S, Hsu KH, Lai $\mathrm{CH}$ : Human papillomavirus genotyping by a polymerase chain reaction-based genechip method in cervical carcinoma treated with neoadjuvant chemotherapy plus radical surgery. Int J Gynecol Cancer 2004; 14:639-649.

15 Kim KH, Yoon MS, Na YJ, Park CS, Oh MR, Moon WC: Development and evaluation of a highly sensitive human papillomavirus genotyping DNA chip. Gynecol Oncol 2006; 100:38-43.

16 Stevens MP, Tabrizi SN, Quinn MA, Garland SM: Human papillomavirus genotype prevalence in cervical biopsies from women diagnosed with cervical intraepithelial neoplasia or cervical cancer in Melbourne, Australia. Int J Gynecol Cancer 2006;16:1017-1024.

17 Lai CH, Huang HJ, Hsueh S, Chao A, Lin CT, Huang SL, Chao FY, Qiu JT, Hong JH, Chou HH, Chang TC, Chang CJ: Human papillomavirus genotype in cervical cancer: a population-based study. Int J Cancer 2007;120: 1999-2006.

18 Vermeulen CF, Jordanova ES, Szuhai K, Kolkman-Uljee S, Vrede MA, Peters AA, Schuuring E, Fleuren GJ: Physical status of multiple human papillomavirus genotypes in flow-sorted cervical cancer cells. Cancer Genet Cytogenet 2007;175:132-137.

19 Pretet JL, Jacquard AC, Carcopino X, Charlot JF, Bouhour D, Kantelip B, Soubeyrand B, Leocmach Y, Mougin C, Riethmuller D; EDITH study group: Human papillomavirus (HPV) genotype distribution in invasive cervical cancers in France: EDITH study. Int J Cancer 2008;122:428-432.

-20 Siriaunkgul S, Suwiwat S, Settakorn J, Khunamornpong $\mathrm{S}$, Tungsinmunkong $\mathrm{K}$, Boonthum A, Chaisuksunt V, Lekawanvijit S, Srisomboon J, Thorner PS: HPV genotyping in cervical cancer in Northern Thailand adapting the liner array HPV assay for use on paraffin-embeded tissue. Gynecol Oncol 2008; 108:555-560.
21 Munagala R, Dona MG, Rai SN, Jenson AB, Bala N, Ghim SJ, Gupta RC: Significance of multiple HPV infection in cervical cancer patients and its impact on treatment response. Int J Oncol 2009;34:263-271.

22 Oh JK, Alemany L, Suh JI, Rha SH, Muñoz N, Bosch FX, Quint W, Lloveras B, Klaustermeier JE, de Sanjosé S, Shin HR: Typespecific human papillomavirus distribution in invasive cervical cancer in Korea, 19582004. Asian Pac J Cancer Prev 2010;11:9931000.

23 Mariani L, Monfulleda N, Alemany L, Vizza E, Marandino F, Vocaturo A, Benevolo M, Quiros B, Lloveras B, Klaustermeier JE, Quint W, de Sanjosé S, Bosch FX: Human papilloma virus prevalence and type-specific relative contribution in invasive cervical cancer specimens from Italy. BMC Cancer 2010;10:259.

24 Munoz N: Human papillomavirus and cancer: the epidemiological evidence. J Clin Virol 2000;19:1-5.

25 Rousseau MC, Pereira JS, Prado JCM, Villa LL, Rohan TE, Franco EL: Cervical co-infection with human papillomavirus (HPV) types as a predictor of acquisition and persistence of HPV infection. J Infect Dis 2001; 184:1508-1517.

26 Liaw KL, Hidesheim A, Burk RD, Gravitt P, Wacholder S, Manos MM, Scott DR, Sherman ME, Kurman RJ, Glass AG, Anderson SM, Schiffman M: A prospective study of human papillomavirus (HPV) types 16 DNA detection by polymerase chain reaction and its association with acquisition and persistence of other HPV types. J Infect Dis 2001; 183:8-15.

27 Lee SA, Kang D, Seo SS, Jeong JK, Yoo KY, Jeon YT, Kim JW, Park NH, Kang SB, Lee HP, Song YS: Multiple HPV infection in cervical cancer screened by HPVDNAchip ${ }^{\mathrm{TM}}$. Cancer Lett 2003;198:187-192. 